\title{
Efficiency of Biocides on the Aquatic Systems Through Bacterial Model
}

\begin{abstract}
ALINA ROXANA BANCIU ${ }^{1}$, LUCIAN IONESCU ${ }^{1}$, DANIELA LILIANA IONICA ${ }^{1}$, DANIEL MITRU ${ }^{1,2}$, MIHAI NITA-LAZAR ${ }^{1 *}$

${ }^{1}$ National Research and Development Institute for Industrial Ecology-ECOIND, 71-72 Drumul Podu Dambovitei, 060652, Bucharest, Romania

${ }^{2}$ Politehnica University of Bucharest, Faculty of Applied Chemistry and Material Science, 1-7 Polizu Str., 011061, Bucharest, Romania

Various biocide technologies have been used successfully in water treatment applications for many years, but their constantly increased production and excessive usage has considerable environmental and economic impacts. In addition, the aggressive use of biocides in more and more fields such as agriculture, livestock growth, and fish farming increased the risk to public health. This measures can lead to the selection of pathogens insusceptible to the main available antimicrobials. Antimicrobials resistance is even more significant when cells are embedded in a biofilm especially in water systems. A variety of microorganisms can be found in swimming pool waters which may be introduced in a number of ways. The disinfection of bathing water is generally achieved by chlorine of chlorine-based products, but alternative more eco-friendly methods such as active oxygen are used more frequently. In this paper, compared the biocides efficiency of two compounds based on chlorine or active oxygen. Although it was assumed that the two biocides have the same mechanism of action and efficiency, we showed in this study that biocides efficiency depends on the bacterial membrane structure and the active oxygen had an increased efficacy against microorganisms compared to chlorine.
\end{abstract}

Keywords: biocides, bacterial resistance, bactericidal efficiency

The continuous and uncontrolled usage of antibacterial agents significantly contributed to bacterial resistance [1]. Resistance has been defined as a temporary or permanent ability of an organism and its progeny to remain viable and / or multiply under conditions that would destroy or inhibit other members of the strain $[2,3]$.

Biocides are chemical components while antimicrobial proprieties and they are widely used for disinfection, antiseptic and preservation purposes to achieve a satisfactory level of hygiene in various settings. The use of biocides has become an integrated part of the industrialized world [4-6], reaching a broad-spectrum of activity due to their multiply and unspecific target sites within microorganisms such as the cytoplasmic membrane, proteins, DNA, RNA and other cytosolic components $[7,8]$.

Unfortunately, the amount of biocides used in the industrial and domestic wastewaters constantly grows and subsequently their presence in the environment, especially in the aquatic system.

The ecosystem balance could be severely impaired by the presence of biocides which [9] could change species community structure or generate new health issues by antimicrobial resistant bacterial strains harmful to human health [10-13].

Water is it an essential element to preserve life but at the same time it is a perfect environment to spread harmful chemical compounds and pathogens. In this respect, both national and European regulations put a special emphasis on the water quality, including the sanitary evaluation of swimming pools. These evaluations based on chemical and microbiological indicators mainly depends on research laboratory, which establish parameters and thresholds for bathing water chemical concentrations. Besides the chemical components the microorganism risks play an important role in modulating the health hazard of particular water bodies. Water in swimming pools can be the source of pathogenic microorganisms creating an epidemiological risk such as Escherichia coli, Pseudomonas aeruginosa, Staphylococcus aureus $[14,15]$.

Several methods such as filtration, ozonation, chlorination and oxygen treatment have been used for maintaining the water quality and to inactivate pathogens and other microorganisms. At the present, more frequently, the disinfection of water relies on chlorine and chlorine-based products $[16,17]$. In spite of the frequent use of those compounds, their target specificity and antimicrobial action are not well understood; however due to their strong oxidizing potential these compounds are believed to react with structural proteins, enzymes and DNA, causing disruption of the cytoplasmic membrane and interference with the cell metabolism [8].

*email: mihai.nita@incdecoind.ro, Phone: +40725919747 
It is known that chlorination of water may lead to formation of unwanted product like haloform [1]. An alternative to chlorination is the usage of active oxygen. This is the extensively used as biocide, particularly in applications where its decomposition into non-toxic by products is important. The basic mechanism of action resumes to chemical oxidation of cellular components $[18,19]$.

Although the Chemical Agencies has approved the use of both types of compounds (chlorine-based product and active oxygen) as biocides, their main difference could resident in their molecular targets and the efficiency against microorganisms.

In this paper, we described the differences in the response of tested microorganisms to the two types of biocides in three levels of concentration and three contact times.

\section{Experimental part}

The biocidal in vitro activity of two types of antimicrobial products, chlorine and active oxygen based, was assessed using a standard method EN 1276 on three reference bacterial strains [20].

The chlorine product was a solid substance containing trichloroisocyanuric acid $(<100 \%$, not clear the $\%$ from what $)$, aluminum sulphate $(<75 \%)$, boric acid $(<5 \%)$ and copper sulphate pentahydrate $(<2.5 \%)$.

The oxygen product was a solid substance based on $100 \%$ pentapotassium bis(peroxymonosulphate) bis(sulphate).

The bacterial strains used during the biocide activity test were purchased from - the International Center for the Authentication, Storage and Production of Microorganisms and Cell Lines (ATCC): Pseudomonas aeruginosa ATCC 15442, Escherichia coli ATCC 10536- and-Staphylococcus aureus ATCC 6538.

According to the standard method, the biocides effects were tested at three different contact times $(5,15$ and $30 \mathrm{~min})$ and three different concentrations for each compound: 2,8 and $20 \mathrm{mg} / \mathrm{L}$ for chlorine or 5,20 and $50 \mathrm{mg} / \mathrm{L}$ for active oxygen. The concentrations indicated by the manufacturer were $8 \mathrm{mg} / \mathrm{L}$ for chlorine and $20 \mathrm{mg} / \mathrm{L}$ for active oxygen.

Each reference strain was seeded, prior biocide effect test, on tryptic soy agar (Oxoid, UK) and incubated for 18-20 hours at $36^{\circ} \mathrm{C} \pm 1{ }^{\circ} \mathrm{C}$. The growth density was spectrophotometrically monitors at $620 \mathrm{~nm}$. The optical densities at of the bacterial strains were within the range recommended by the standard method: $1.72 \mathrm{OD}_{600 \mathrm{~nm}} P$ s. aeruginosa, $1.46 \mathrm{OD}_{600 \mathrm{~nm}}$ E. coli or $1.65 \mathrm{OD}_{600 \mathrm{~nm}} S$. aureus were incubated on tryptic soy agar in absence (control) or presence of biocide at $37^{\circ} \mathrm{C} \pm 1^{\circ} \mathrm{C}$ for 24 hours. All tests were performed in duplicate.

The bacterial viability was analyzed by counting the colony forming units per milliliter $(\mathrm{CFU} / \mathrm{mL})$ developed during 24 of incubation.

\section{Results and discussions}

Bacterial strains incubated in presence of chlorine biocide were affected regardless of biocide concentration or contact time (Fig. 1). The biocide effect was very potent on all three tested strains since a concentration of $2 \mathrm{mg} / \mathrm{L}$ chlorine decreased bacterial growth up to $50 \%$ in 5 min of contact.

The middle concentration of $8 \mathrm{mg} / \mathrm{L}$ chlorine product, recommended concentration in the data sheet, decreased the bacterial density of Ps. aeruginosa up to $70 \%$ after 5 minutes and up to $90 \%$ after 30 minutes of contact time. In the same conditions, a dramatic decrease of the E. coli colonies count, up to $90 \%$ inhibition could be observed at concentration of $8 \mathrm{mg} / \mathrm{L}$ after 15 minutes' contact time and $48 \mathrm{~h}$ incubation (data not shown).

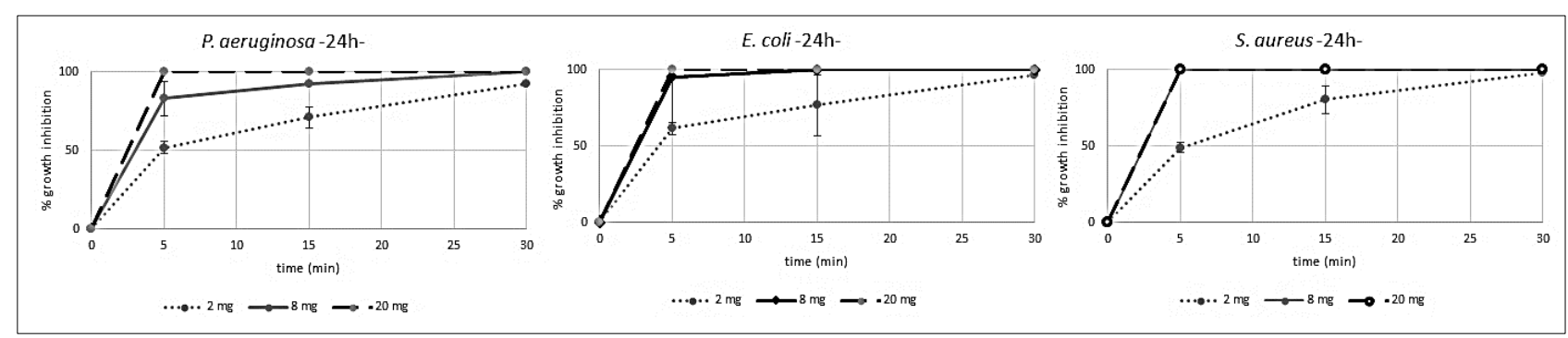

Fig. 1. Variation of growth inhibition of bacterial density under the effect of different concentration and contact time of chlorine biocide compared to control, untreated bacteria. All studies represent one of two independent experiments.

S. aureus, a Gram positive bacteria, showed less resistance to the biocide, especially at higher concentrations, than the other two bacterial strains which were Gram negative (Fig. 1). This effect could be explained by the fact that a Gram positive bacterial structure has only membrane which could allow an easier passage of the biocide inside bacterium and subsequently a more toxic potential of the antibacterial product. The Gram negative strains have an extra outer membrane which is an extra barrier impeaching the biocide passage into the bacterium. 


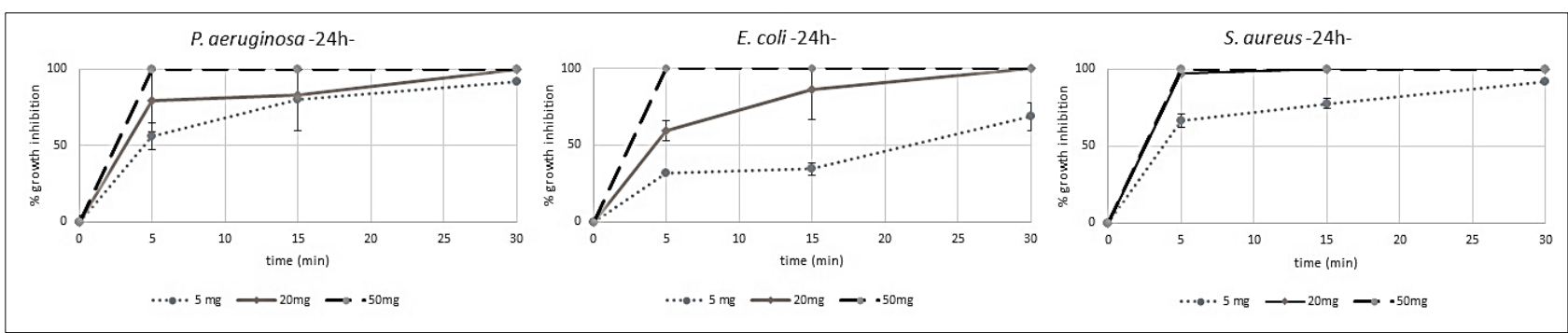

Fig. 2. Variation of growth inhibition of bacterial density under the effect of different concentration and contact time of active oxygen biocide compared to control, untreated bacteria. All studies represent one of two independent experiments.

The colony counts of Ps. aeruginosa indicated a constant decrease of bacterial viability by about $50 \%$ at the minimum concentration of $5 \mathrm{mg} / \mathrm{l}$ active oxygen biocide up to $70 \%$ at the middle concentration of $20 \mathrm{mg} / \mathrm{L}$ (Fig. 2). E. coli seemed to be less sensitive to active oxygen at the lower concentration (up to $30 \%$ inhibition) for a longer exposure time, up to $15 \mathrm{~min}$.

The results showed that after exposure of the bacterial suspension to a minimum biocidal concentration for 5 or 15 minutes the number of colony count remains constantly low compared to the initial density. On the other hand, the number of $E$. coli bacteria decreases by $60 \%$ after 30 minutes of contact with biocide.

E. coli incubated 5 or $10 \mathrm{~min}$ in presence of the recommended concentration $(20 \mathrm{mg} / \mathrm{L}$ active oxygen $)$ were inhibited between 60 to $85 \% .30$ minutes' contact time induced $100 \%$ bacterial growth inhibition.

The bactericidal effect of the active oxygen was more potent on Gram positive $S$. aureus but the action over a long time of exposure can obtained in the application of the minimum concentration (Fig. 2).

It was interested to see that $50 \%$ bacterial inhibition was reached at around the recommended biocide concentration, $7 \mathrm{mg} / \mathrm{L}$ chlorine and $20 \mathrm{mg} / \mathrm{l}$ active oxygen and this tendency was maintained during bacteria-biocide contact time when it was compared to the control, untreated bacteria (Fig $3 \mathrm{~A}, \mathrm{~B}$ and $\mathrm{C}$ ). The biocides had a different efficiency based on their concentration needed to reach $50 \%$ bacterial growth inhibition regardless of bacterial structural characteristics. In this respect, the chlorine based biocid induced $50 \%$ bacteria growth inhibition at $7 \mathrm{mg} / \mathrm{L}$ and it is more efficient than active oxygen based biocid (50\% bacterial growth inhibition reached at $20 \mathrm{mg} / \mathrm{L}$ ).

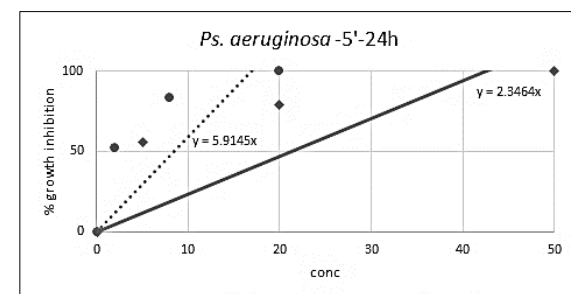

- $\mathrm{Cl} \quad 02 \cdots . .$. Linear (Cl) - Linear (02)

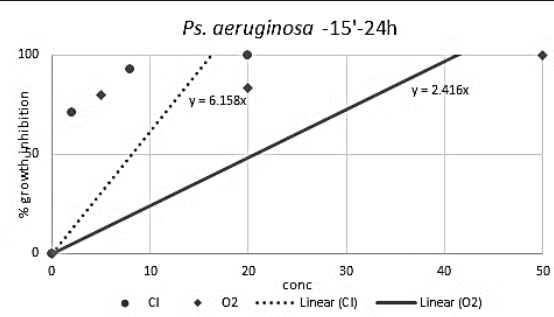

a)

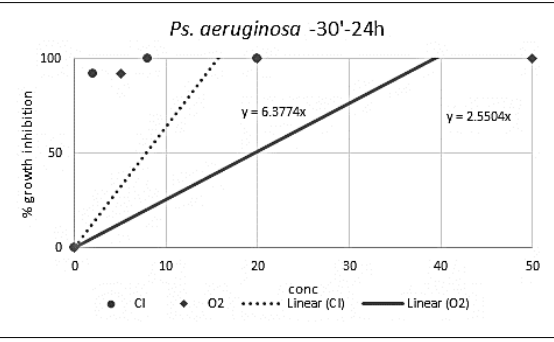

- $\mathrm{cl} \cdot 02 \ldots \ldots .$. Linear (C) $)$ L Linear (102)

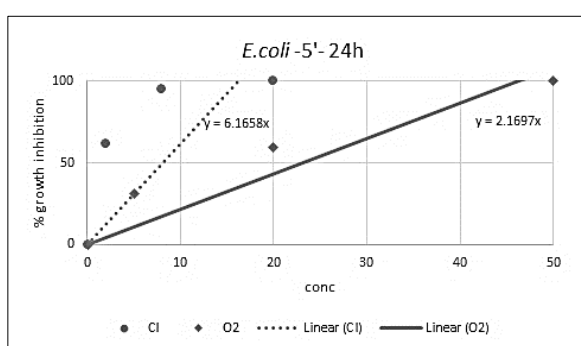

- $\mathrm{Cl} \quad 02 \quad \cdots . .$. Linear (Cl) - Linear (02)

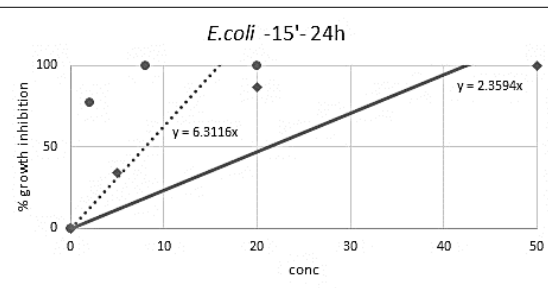

- $\mathrm{Cl} \quad 02 \cdots \ldots$ Linear (Cl) - Linear (02)

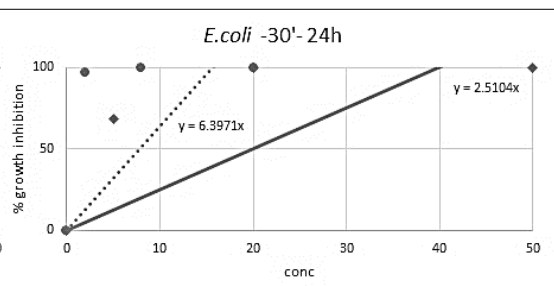

- $\mathrm{Cl} \cdot 02 \ldots . .$. Linear (Cl) - Linear (02)

b)

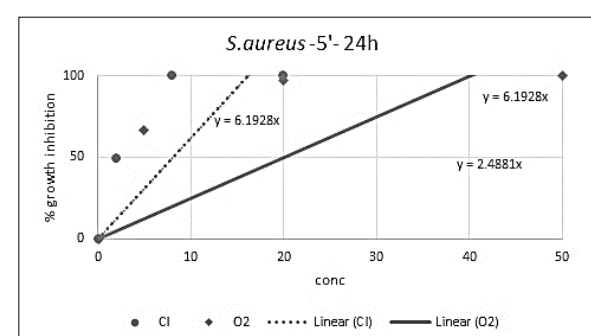

- $\mathrm{Cl} \quad 02 \cdots \ldots$ Linear (Cl) - Linear (02)

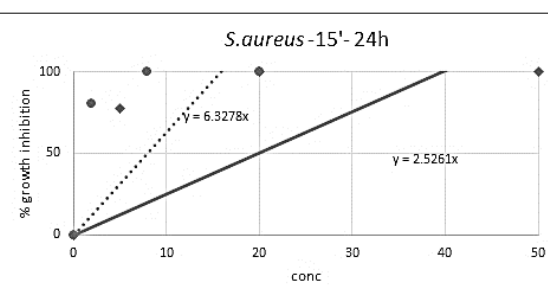

- Cl $\quad 02 \quad \cdots \ldots$ Linear $(\mathrm{Cl})$ - Linear (02)

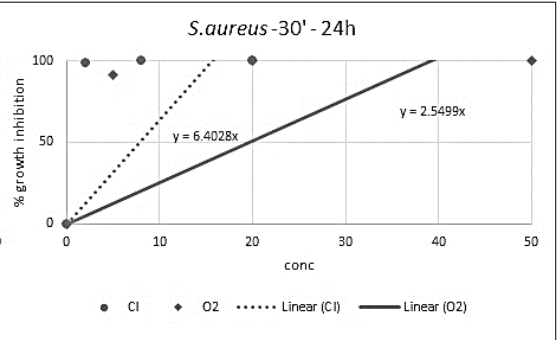

- Cl $\quad 02$...... Linear (Cl) —Linear (02)

c)

Fig. 3. The link between $50 \%$ bacterial growth inhibition and the dose efficiency of chlorine and active oxygen biocides during the time compared to control, untreated bacteria: a) Ps. aeruginosa; b) E. coli and c) S.aureus.

All studies represent one of two independent experiments 
In spite of using a less amount of chloride based biocide to reach a higher bacterial growth inhibition, this compound could generate by products which could be more toxic to the bacteria and environment. On the other hand, the active oxygen-based biocide is less efficient and it is needed in a higher concentration, up to three folds compared to chlorinebased biocide, to induce the same toxic effect, but on the long term, there are no toxic by product.

\section{Conclusions}

Evaluating the efficiency of two types of biocide products indicated that both chlorine and oxygen biocides at middle range concentrations (7-20 mg/l) had a bactericidal effect after contact to bacterial suspensions. The E. coli strain seemed to have the highest resistance to these biocides at low concentrations and contact times.

Testing a lower concentration than recommended in the manufacturer's data sheet demonstrated that the action of the biocides was influenced over time.

Bacterial density decreased in direct proportion with the increase of exposure time to the biocides.

Applying a higher biocide concentration than the recommended one induced a rapid inhibitory effect in a very short period of time.

The differences between the biocides structure seemed to modulate the inhibitory effect on specific bacterial strains.

The results showed that the membrane wall of Gram negative bacteria confers greater resistance to the biocides action, regardless of the biocide chemical composition.

Acknowledgements: The authors acknowledge the financial support offered by The National Research CORE Program through Agreement no. 38N/2018, Project code PN 18050101.

\section{References}

1.BRAOUDAKI M., HILTON A.C., Clin. Microbiol., 42, 2004, p. 73.

2.CLOETE T.E., Int. Biodet. Biodeg., 51, no. 40, 2003, p. 277.

3.ROBERTSON PK., BLACK KD., ADAMS M., WILLIS K., BUCHAN F., ORR H., LAWTON L., MCCULLAGH C., J. Photochem. Photobiol. B., 95, no. 1, 2009, p. 58.

4.GHEORGHE S., PETRE J., LUCACIU I., Environ. Monitor. Assess., 188, no. 6, 2016, p 379.

5.COWIESON AJ., KLUETER AM., Amin. Feed. Sci. Technol., 55, 2018.

6.WITTMER IK., BADER HP., SCHEIDEGGER R., SINGUR H., LUCK A., HANKE I., CARLSSON C., STAMM C., Water. Res., 44, no. 9, 2010, p. 2691.

7.PHULL S.S., NEWMAN A.P., LORIMER J.P., POLLET B., MASON T.J., Ultrason. Sonochem., 4, 1997, p. 157.

8.SEIER-PETERSEN M.A., PhD Thesis at Technical University of Denmark, 2013.

9.STOICA S., VASILE G. G., BANCIU A., NICULESCU D., LUCACIU I., NITA-LAZAR M., Rev. Chim. (Bucharest), 68, no. 8, 2017 , p. 1744. 10.BANCIU A., NITA-LAZAR M., NICULESCU D., $20^{\text {th }}$ International Symposium “The Environment and the Industry”, SIMI, 2017, p. 248.

11.BANCIU A., NICULESCU D., NITA-LAZAR M., J. Environ. Prot. Ecol., 17, no. 1, 2016, p. 127.

12.GHEORGHE S, STOICA C, LUCACIU I, BANCIU A, LAZAR MN, Rev. Chim (Bucharest), 70, no. 1, 2019, p. 307.

13.GHEORGHE S, LUCACIU I, GRUMAZ R, STOICA C, J. Environ. Prot. Ecol., 13, no. 2, 2012, p. 541.

14.WYCZARSKA-KOKOT J., ACEE Journal, 4, 2009, p. 145.

15.LAZAR MN, GHEORGHE S, ANGHELACHE A, BANCIU A, STOICA C, LUCACIU I, Rev. Chim (Bucharest), 67, no. 8, 2016, p. 1454.

16.BORGMANN-STRHSEN R., Int. Biodet. Biodeg. 51, no. 4, 2003, p. 291.

17.BOTLAGUNTA M., BONDILI J., PARDHASARADHI M., Asian. J. Pharm. Clin. Res., 8, no. 1, 2015, p. 20.

18.FINNEGAN M., LINLEY E., DENYER S.P., MCDONNELL G., SIMONS C., MAILLARD J.Y., J. Antimicrob. Chemother., 65, no. 10, 2010, p. 2108.

19.LINLEY E., DENYER S.P., MCDONNELL G., SIMONS C., MAILLARD J.Y., J. Antimicrob. Chemother., 67, 2012, p. 1589.

$20 . * * *$ EN 1276, Chemical disinfectants and antiseptics - Quantitative suspension test for the evaluation of biocidal activity of chemical disinfectants and antiseptics used in food, industrial, domestic and institutional areas - Test method and requirements (phase 2, step 1).

Manusript received: 31.07 .2019 
